\title{
Distant Strangers and Standing in Polisario
}

\author{
Aravind Ganesh"
}

\section{Introduction}

Rules of procedure, such as those concerning standing to bring suit, lie at the very heart of what it means to be a legal subject empowered with rights. This contribution demonstrates this in the context of the recent Polisario cases before the EU courts, the latest instalment in the decades-long legal struggle over the Western Sahara between Morocco and the national liberation movement known as the Frente Popular de Liberación de Saguía-elHamra y Río de Oro (Front Polisario). ${ }^{1}$ In particular, it considers the ways in which the various courts of the EU interpreted the rules of EU law on standing to bring judicial review, with a view to assessing whether it is true that the EU legal order offers all possible claimants a "complete system of remedies". ${ }^{2}$ It concludes that this claim is untrue, and that a gap presents itself where the EU enters into a treaty with another entity with sovereign powers ('state', for convenience) which disposes of the territory, natural resources, and consequently also people of a third state. We term such people 'distant strangers' because they are neither citizens of EU Member States nor are they present on Member State territory. Both the third state and its people have valid grievances against the EU. Nevertheless, they are barred from seeking appropriate judicial review of EU acts.

The first item of interest is the December 2015 judgment of the General Court of the European Union (General Court), which partially annulled a

* Research Fellow at the Max Planck Institute Luxembourg for Procedural Law.

1 That 'legal struggle' began with the advisory opinion of the International Court of Justice in Western Sahara, Advisory Opinion, ICJ Reports 1975, 12.

2 Unión de Pequeños Agricultores v. Council, Case C-50/00, Judgment of 25 July 2002, [2002] ECR I-6677, paras. 28, 40; Commission v. Jégo-Quéré, Case C-263/02 P, Judgment of 1 April 2004, [2004] ECR I-3425, para. 30; Rothleyand and Others v. Parliament, Case C-167/02 P, Judgment of 30 March 2004, [2004] ECR I-3149, para. 46; and Gaston Schul Douane-expediteur, Case C-461/03, Judgment of 6 December 2005, [2005] ECR I-10513, para. 22. 
Council decision adopting a modification ${ }^{3}$ of the Association Agreement between the EU and Morocco which would have applied to fisheries and other agricultural exports coming from the territory of the Western Sahara. ${ }^{4}$ The General Court held that the Front Polisario had standing to challenge the Council decision directly, and that the measure was to be annulled in part, due to a failure by the EU institutions to assess the implications of the Association Agreement for the exploitation of natural resources and the human rights of the inhabitants of the Western Sahara. Secondly, we have the advisory opinion by AG Wathelet, in which he offered three different theories, two of which would have reversed the General Court's decision. ${ }^{5}$ The first theory was that the Association Agreement was not to be interpreted as applying in the Western Sahara territory, meaning that the Front Polisario had no legal interest at stake, and therefore lacked standing. The second theory was that the Front Polisario lacked standing because the Council decision was not of 'direct and individual concern' to it. AG Wathelet's third theory upheld the General Court's decision in full. Finally, there is the December 2016 judgment of the CJEU, which adopted the first of AG Wathelet's theories. ${ }^{6}$

The decision has been hailed as a sensational 'victory through defeat' for the Front Polisario, in that it secured its political objective of preventing the application of the Association Agreement over the Western Sahara despite 'losing' the dispute on procedural grounds, thus forcing a fundamental realignment of EU-Morocco relations in its favour. ${ }^{7}$ Nevertheless, as will be argued, the CJEU decision is essentially a denial of accountability. Be-

3 Simon and Rigaux observe that the General Court inaccurately describes the contested measure as adopting a 'conclusion' of the EU-Morocco Association Agreement. D. Simon and A. Rigaux, Le Tribunal et Le Droit International Des Traités: Un Arrêt Déconcertant (Trib. UE, 10 Déc. 2015, Aff. T 512/12, Front Polisario c/ Conseil soutenu par Commission), 2 Europe: Actualité Du Doit de L'union Européenne (2016), 5, para. 2.

4 Front Polisario v. Council, Case T-512/12, Judgment of 10 December 2015, ECLI:EU:T:2015:953.

5 Council v. Front Polisario, Case C-104/16, Opinion (AG Wathelet) of 13 September 2016, ECLI:EU:C:2016:677.

6 Council v. Front Polisario, Case C-104/16, Judgment of 21 December 2016, ECLI:EU:C:2016:973.

7 C. Ryngaert, 'The Polisario Front Judgment of the EU Court of Justice: A Reset of EU-Morocco Trade Relations in the Offing' (2017), available at http:// blog.renforce.eu/index.php/en/2017/01/15/the-polisario-front-judgment-of-the-eucourt-of-justice-a-reset-of-eu-morocco-trade-relations-in-the-offing-2/ (last visited 29 September 2018), (observing that the "dismissal of the Polisario Front's action may appear to be a victory for the EU Council and Morocco. However, in a manner 
fore these claims can be elaborated upon, a brief summary is needed of the law on standing to bring direct challenges against EU acts.

\section{Standing under EU law}

The starting point for our inquiry is Article 263 TFEU, which sets out the conditions individual applicants must fulfil in order to seek 'direct' judicial review of an EU measure. There are other 'indirect' methods by which EU measures may be challenged. Firstly, there are preliminary references from national courts under Article 267 TFEU, which are the means by which most EU litigation is brought, and in fact the engine of the vast majority of seminal EU jurisprudence. ${ }^{8}$ Secondly, claimants may invoke Article 277 TFEU, which allows parties to plead the illegality or inapplicability of EU acts in proceedings brought against them by EU institutions.

\section{A. Legal effects}

The kinds of measures subject to judicial review are specified in the first subparagraph of Article 263 TFEU:

The Court of Justice of the European Union shall review the legality of legislative acts, of acts of the Council, of the Commission and of the European Central Bank, other than recommendations and opinions, and of acts of the European Parliament and of the European Council intended to produce legal effects vis-à-vis third parties. It shall also review the legality of acts of bodies, offices or agencies of the Union intended to produce legal effects vis-à-vis third parties.

reminiscent of Pyrrhus's battles with the Romans in the 3rd century BC, it may well turn out [not] to be a loss, and in fact a boon for the Saharawi."); EUObserver, 'Top Court Strikes down EU Western Sahara Policy' (2017), available at https:// euobserver.com/foreign/136401 (last visited 14 June 2017).

8 P. Craig and G. de Búrca, EU Law: Text, Cases, and Materials, 5th ed. (2015), 464 ("Article 267 TFEU is one of the most important Treaty provisions. There would have been few, at the inception of the Treaty, who would have guessed its significance in shaping EU law [...] [It] is the 'jewel in the Crown' of the Court's decision..). 
The upshot of this provision is that the measure must produce 'legal', rather than just 'factual' effects. ' While the literature and jurisprudence often subsumes this requirement under the broader requirement of 'direct concern' discussed below, ${ }^{10}$ it is submitted that considerable advantage is gained by elucidating the concept of a 'legal effect' separately. In this regard, the crucial point is that the measure must change not just the applicant's factual situation, but their legal rights and obligations. To illustrate, consider a gunman who robs you of your purse. He certainly produces factual effects upon you insofar as he deprives you of the purse, but he does not change your legal position with respect to it. The purse remains yours by right, and the purpose of a legal remedy is to represent this. ${ }^{11}$ In contrast, an official who commands you to hand over your purse - say, in payment of a fine - does produce legal effects upon you. You now have an obligation to hand over the purse, where previously you had none. The same is true of a trustee who wrongfully sells your trust property to an innocent purchaser for value. Your property in the thing is gone, and all you are left with is a personal claim against the trustee. Put simply, a measure changing a person's legal position does not simply purport to 'affect' a person, but to govern her.

9 Inuit Tapiriit Kanatami et al. v. Parliament \& Council, Case C-583/11, Judgment of 3 October 2013, ECLI:EU:C:2013:625, para. 56 ("Given the reference to 'acts' in general, the subject matter of those limbs of Article 263 is any European Union act which produces binding legal effects."); IBM v. Commission, Case 60/81, Judgment of 11 November 1981, [1981] ECR 2639, para. 9; Athinaïi Techniki v. Commission, Case C-521/06 P, Judgment of 17 July 2008, [2008] ECR I-5829, para. 29; NDSHT v. Commission, Case C-322/09 P, Judgment of 18 November 2010, [2010] ECR I-11911, para. 45; and Deutsche Post v. Commission, Joined Cases C-463/10 P and C-475/10 P, Judgment of 13 October 2011, [2011] ECR I-9639, paras. 36-38.

10 M. Rhimes, The EU Courts Stand Their Ground: Why Are the Standing Rules for Direct Actions Still So Restrictive, 9 European Journal of Legal Studies (2016), 103, 108 ("Direct concern requires two cumulative sub-criteria to be met. First the measure must directly affect the legal situation of the person concerned [...] Second, the implementation of that measure must be purely automatic, resulting from Union norms without the application of other intermediate rules.”); BUPA and others v. Commission, Case T-289/03, Judgment of 12 February 2008, [2008] ECR II-81, para. 81 ("it has consistently been held that the contested measure must directly produce effects on the legal situation of the person concerned and its implementation must be purely automatic and follow solely from the Community rules, without the application of other intermediate measures.").

11 See generally A. Ripstein, Private Wrongs (2016), chapter 8. 
The purpose of direct judicial review in EU law is to allow individuals the ability to challenge abuses of authority by EU institutions. ${ }^{12}$ This is reflected in the grounds of review, listed in Article 263(2) TFEU as "lack of competence, infringement of an essential procedural requirement, infringement of the Treaties or of any rule of law relating to their application, or misuse of powers". In contrast, the preliminary ruling procedure under Article 267 TFEU provides abstract, constitutional review; it ensures the uniform interpretation and application of EU law by Member State courts. ${ }^{13}$ It is not "a dispute resolution procedure [... but] a non-contentious stage in the procedure before the national court". ${ }^{14}$ Finally, EU law provides means for seeking redress for wrongful factual effects or losses caused by EU institutions. These are addressed by actions for damage under Article 340 TFEU. ${ }^{15}$ Together, these avenues for indirect and direct challenge make up the aforementioned 'complete system of remedies.' 16

Notwithstanding the centrality of the legal effects requirement in preserving this division of labour in the Treaties, EU courts have sometimes been quite flexible in their understanding of it. ${ }^{17}$ In her opinion in Inuit II, AG Kokott even suggested doing away with the legal effects requirement, observing that individuals had "perfectly correctly" been recognized as possessing standing to challenge State Aid authorizations and merger approvals, which she depicted as producing only factual effects. ${ }^{18}$ Her characterization is not quite correct. Decisions to authorize new concentrations

12 Commission v. Council, Case 22/70, Judgment of 31 March 1971, [1971] ECR 263, para. 41 ("An action for annulment must therefore be available in the case of all measures adopted by the institutions, whatever their nature or form, which are intended to have legal effects.").

13 Rhimes, supra note 10, 160.

14 M. Broberg and N. Fenger, Preliminary References to the European Court of Justice (2014), 279-280.

15 Craig and Búrca, supra note 8, 583. ("In any developed legal system there must be a mechanism whereby losses caused by governmental action may be recovered by an action brought by an individual... Compensation against the EU is governed by Article 340 TFEU (ex Article 288 EC).”).

16 See Inuit, Judgment, supra note 9, paras. 90, 92; Telefónica SA v. European Commission, Case C-274/12 P, Judgment of 19 December 2013, ECLI:EU:C:2013:852, para. 57.

17 See e.g. Council v. Parliament, Case 34/86, [1986] ECR 2155, Judgment of 3 July 1986, (holding a declaration by the President of the European Parliament relating to the final adoption of the general budget of the then European Community as productive of legal effects upon third parties, and therefore reviewable.).

18 Inuit Tapiriit Kanatami et al. v. Parliament \& Council, Case C-583/11, Opinion (AG Kokott) of 17 January 2013, ECLI:EU:C:2013:21, para. 71. Citing Cofaz and 
or issue subsidies to particular firms do not simply affect the factual position of other market participants, say, like a competitor coming up with a better product, or a supplier demanding a higher price for an input. These kinds of effects are caused by persons with whom applicants are on equal footing. In contrast, a decision to authorise a merger or State aid modifies the very terms on which the market participants interact with one another, and can therefore be taken only by a public authority. The decision-maker is not an equal, but occupies a hierarchically superior position to them. Market participants are not just affected by such decisions, but governed by them.

\section{B. Direct and Individual Concern}

After listing a number of 'privileged applicants' - Member States and EU institutions - that are allowed standing on easier terms, the fourth subparagraph of Article 263 TFEU provides that:

Any natural or legal person may, under the conditions referred to in the first and second subparagraphs, institute proceedings against an act addressed to that person or which is of direct and individual concern to them, and against a regulatory act which is of direct concern to them and does not entail implementing measures.

This provision, and in particular the concept of a 'regulatory act', was introduced by the Treaty of Lisbon, using language lifted verbatim from Article III-365(4) of the failed Treaty on a Constitution for Europe (Constitutional Treaty). Under the former Article 230 TEC, ordinary applicants could seek judicial review only of EU measures that were either explicitly addressed to them, or which were of 'direct and individual concern' to them. As is well known, the CJEU had interpreted these requirements extremely narrowly,

Others v. Commission, Case 169/84, Judgment of 28 January 1986, [1986] ECR 391; Spain v. Lenzing, Case C-525/04 P, Judgment of 22 November 2007, [2007] ECR I-9947 (confirming or taking for granted the standing of competitors to institute proceedings against Commission decisions to authorize State aid); BaByliss v. Commission, Case T-114/02, Judgment of 3 April 2003, [2003] ECR II-1279, para. 89; ARD v. Commission, Case T-158/00, Judgment of 30 September 2003, [2003] ECR II-3825, para. 60 (recognizing standing of competitors to challenge Commission decision to authorize concentrations.). 
and in a manner that excluded most applicants. ${ }^{19}$ According to the jurisprudence, a measure is of 'direct concern' if, in addition to producing legal effects, its operation involves no "autonomous will" interposing itself between the EU and the applicant. This may either be because the measure is directly effective, or because it "leaves no room for any discretion" on the part of any intermediaries. ${ }^{20}$ The direct concern requirement was left unchanged by Lisbon. ${ }^{21}$

The more onerous requirement is of 'individual concern.' In the infamous Plaumann decision, the CJEU held that this required a challenged measure to "affect [the applicant] by reason of certain attributes which are peculiar to them or by reason of circumstances in which they are differentiated from all other persons".22 In that case, an importer of clementines had challenged a decision not to lower import taxes on that fruit, in circumstances where it was clear that that measure would have had effects uniquely upon it. Nonetheless, the plaintiff was held to lack standing because in principle, any other undertaking could have chosen to enter that market. The stringency of the individual concern requirement was demonstrated in Codorniu, which involved a direct challenge by a Spanish producer of sparkling wine against an EU measure prohibiting producers outside France and Luxembourg from calling their product 'crémant.'23 Unlike the applicant in Plaumann, the applicant in Codorniu satisfied the individual concern requirement because it had obtained a trademark over that appel-

19 For representative readings, see A. Arnull, Private Applicants and the Action for Annulment under Article 173 of the EC Treaty, 32 Common Market Law Review (1995), 7; P. Craig, Standing, Rights, and the Structure of Legal Argument, 9 European Public Law (2003), 493; C. Koch, Locus Standi of Private Applicants under the EU Constitution: Preserving Gaps in the Protection of Individuals Right to an Effective Remedy, 30 European Law Review (2005), 511.

20 Parti écologiste “Les Verts" v. Parliament, Case 294/83, Judgment of 23 April 1986, [1986] ECR 1357, para. 31.

21 See e.g. EREF v. Commission, Case T-694/14, Order of 23 November 2015, not reported, para. 17; Inuit, Opinion, supra note 18, paras. 68-69; Microban and another v. Commission, Case T-262/10, Judgment of 25 October 2011, [2011] ECR II-7697, para. 32; K. Lenaerts et al., EU Procedural Law (2014), 335-336 (section 7.109); Rhimes, supra note 10, 106-135.

22 Plaumann v. Commission, Case 25/62, Judgment of 15 July 1963, [1963] ECR 95, 107. See Lenaerts et al., supra note 21, 326 (section 7.100) ("An applicant can show in only limited ways that it is individually concerned by a measure of general application."); Rhimes, supra note 10, 145 ("As is known, it is nearly impossible to show individual concern in relation to [a legislative] act.").

23 Codorníu SA v. Council, Case C-309/89, Judgment of 18 May 1994, [1994] ECR I-01853. 
lation in Spain, thereby effectively creating a new market which no other Spanish producer could enter. In short, standing to bring judicial review was available under the Article 230 TEC regime only against measures effectively amounting to bills of attainder: the challenged measure had either to address the applicant personally by name, or single out that applicant with such surgical precision that it might as well have identified her by name.

This state of affairs unsurprisingly elicited almost universal criticism from academia, ${ }^{24}$ the General Court, ${ }^{25}$ and even numerous Advocates General, ${ }^{26}$ such that change was felt to be necessary by the time of the Constitutional Treaty. ${ }^{27}$ This was the context in which Article 263 TFEU entered into force. However, the Lisbon drafters had left the term 'regulatory act' undefined, thus necessitating judicial clarification. ${ }^{28}$ This was duly provided in Inuit II, where the General Court, Advocate General, and CJEU all joined in defining regulatory acts as "acts of general application other than legislative acts". ${ }^{29}$ Accordingly, 'regulatory act' was to be understood in contradistinction with 'legislative act', a term mentioned in the first paragraph of Article 263 TFEU and defined in Article 289 TFEU as acts jointly passed by the Parliament and the Council, as well as by some other procedures. With respect to regulatory acts that not entailing implementing measures, applicants may bring direct challenges without having to satisfy the individual concern requirement.

For legislative acts not addressed to the applicant, however, the exacting standards of direct and individual concern continue to apply. AG Kokott justified the special defence shown to legislative acts by arguing that they were taken by bodies endowed with "particularly high democratic legiti-

24 See sources listed in supra note 19.

25 See Jégo-Quéré v. Commission, Case T-177/01, Judgment of 15 January 2003, [2002] ECR II-2365.

26 See e.g. Unión de Pequeños Agricultores v. Council, Case C-50/00 P, Opinion (AG Jacobs) of 21 March 2002, [2002] ECR I-6681; Extramet v. Council (Admissibility), Case C-358/89, Opinion (AG Jacobs) of 21 March 1991, [1991] ECR I-2507; British American Tobacco (Investments) Ltd and Imperial Tobacco, Case C-491/01, Opinion (AG Geelhoed) of 10 September 2002, [2002] ECR I-11461.

27 Inuit, Opinion, supra note 18, paras. 1-2.

28 Ibid., para. 30 (observing that "regulatory act" was "an expression that is not defined anywhere in the treaties."); D. Chalmers, G. Davies and G. Monti, European Union Law: Text and Materials (2014), 414-415.

29 Inuit Tapiriit Kanatami, Case T-18/10, Judgment of 6 September 2011, [2011] ECR II-05599, para. 56; Inuit, Opinion, supra note 18, para. 47; Inuit, Judgment, supra note 9, para. 60. 
mation" 30 - the EU Parliament and the Council. Moreover, she added that sufficient judicial protection was afforded by the preliminary ruling and annulment procedures, ${ }^{31}$ even though she acknowledged that "merely indirect examination of the lawfulness of a legislative act [might not constitute] an adequate substitute for the lack of a direct legal remedy", and that an individual ought not be required to run the risk of legal sanctions in proceedings brought against them in order to contest the legality of EU acts. ${ }^{32}$ The CJEU concurred with her in the decision that followed, holding that the relevant travaux préparatoires for the Constitutional Treaty envisaged a general liberalization of standing rules, except with respect to challenges against legislative measures. ${ }^{33}$

The measure challenged in the Polisario litigation was a 'legislative act' within the terms of Article 263(4) TFEU, and was not directly addressed to the Front Polisario. ${ }^{34}$ As such, the Plaumann standard applied in full. For present purposes, we leave aside questions about the democratic credentials of the Parliament and Council, as well as whether judicial review of legislation can be curtailed for such reasons. ${ }^{35}$ Obviously, neither the Front Polisario nor distant strangers such as individual Sahrawis ever conferred any democratic imprimatur upon the EU Parliament and Council. Nor is it possible for non-EU Member State courts to request preliminary rulings. As such, the crucial question is whether the EU ever creates legal effects upon distant strangers such as the Sahrawis. If it does, then the requirements of direct and individual concern will pose unjustifiable barriers to the applicant distant strangers. We turn now to this question.

30 Inuit, Opinion, supra note 18, para. 38. See B. Libgober, Can the EU Be a Constitutional System without Universal Access to Judicial Review?, 36 Michigan Journal of International Law (2014), 353 (defending the EU's claim to be a constitutional order adhering to the rule of law, on the grounds that in many EU Member States, the rules of standing for judicial review of legislation are equally, if not more strict.).

31 Inuit, Opinion, supra note 18, para. 117.

32 Ibid.

33 Inuit, Judgment, supra note 9, para. 59, citing Secretariat of the European Convention, Final report of the discussion circle on the Court of Justice of 25 March 2003, CONV 636/03, para. 22, and Cover note from the Praesidium to the Convention of 12 May 2003, CONV 734/03, 20.

34 Front Polisario v. Council, supra note 4, paras. 71-73.

35 See e.g. Unión de Pequeños Agricultores, Opinion, supra note 26, para. 86; Rhimes, supra note 10,142-143 (arguing that arguments from legislative deference prove "too little", because the unelected Council carries as much weight as the Parliament in the ordinary legislative procedure under Article 289(1) TFEU, as well as "too much", because legislative acts can be challenged indirectly anyway.). 


\section{Does the EU create legal effects extraterritorially?}

As argued above, to produce legal effects upon persons is to change their legal rights and obligations; in other words, to 'govern' them. This immediately presents a problem: does the EU ever govern distant strangers such as the Sahrawis? In a paper published before the Polisario litigation, Bartels raised precisely this issue in considering whether Articles 3(5) and 21 TEU impose any 'extraterritorial' human rights obligations upon the EU. He rightly distinguishes between policies which merely produce effects of concern to the human rights of persons overseas, and those that actually violate human rights overseas. He proceeds to argue that where the former are concerned, Articles 3(5) and 21 TEU impose a minimal duty to 'respect'; that is, not to cause harm to distant strangers. There are no 'positive' duties; that is, to 'protect' distant strangers from violations of their human rights by third persons, or 'fulfil' their rights by providing needed facilities and resources. ${ }^{36}$

Crucially, however, Bartels argues that the minimal duty to respect will in most cases be unenforceable because of the requirement of legal effects in order to obtain standing to bring judicial review. ${ }^{37}$ In this connection, he cites the Commune de Champagne decision, in which the General Court

36 L. Bartels, The EU's Human Rights Obligations in Relation to Policies with Extraterritorial Effects, 25 European Journal of International Law (2014), 1071, 1078-1087. In his short response to Bartels's piece, Cannizzaro invokes “restraints flowing from the founding treaties" to deny that Articles 3(5) and 21 TEU require even Bartels's minimal duty of respect. E. Cannizzaro, The EU's Human Rights Obligations in Relation to Policies with Extraterritorial Effects: A Reply to Lorand Bartels, 25 European Journal of International Law (2014), 1093, 1095. In particular, Cannizaro argues that Article 21 TEU is limited to the Common Security and Foreign Policy [CFSP] pillar, on the basis that "Article 23 [TEU] assigns the pursuit of the political objectives laid down by Article 21(1) and (2) to the primary competence of the CFSP.', ibid., 1098. Bartels responds correctly that Article 23 TEU provides instead that the conduct of the CFSP "shall be guided by the principles, shall pursue the objectives of, and be conducted in accordance with" the general provisions on EU external relations (such as Article $21 \mathrm{TEU}$ ), and thus cannot be understood to mean the CFSP is the only means by which the political objectives in Article 21 TEU are to be pursued. L. Bartels, 'The EU's Human Rights Obligations in Relation to Policies with Extraterritorial Effects: Rejoinder to Enzo Cannizzaro', available at http://www.ejiltalk.org/rejoinder-to-enzo-cannizzaro/ (last visited 15 November 2018). Bartels's approach was subsequently confirmed in Parliament v. Council, Case C-263/14, Judgment of 14 June 2016, ECLI:EU:C:2016:435, para. 47; Parliament v. Council, Case C-263/14, Opinion (AG Kokott) of 28 October 2015, ECLI:EU:C:2015:729, para. 72.

37 Bartels, supra note 36, 1987-1990. 
denied certain Swiss applicants standing to challenge an act of the EU approving a series of international agreements between the EU and Switzerland, by which wines from the Commune of Champagne in the Canton of Vaud were prohibited from being marketed in the EU under the name of 'Champagne.' The General Court recognized that the agreements between the EU and Switzerland did indeed change the legal position of the applicants, but that as bilateral acts they were not judicially reviewable under the then Article 230 TEC. ${ }^{38}$ Instead, only the EU act adopting those agreements could be so challenged. ${ }^{39}$ The General Court then invoked the principle of sovereign equality in Article 2(1) UN Charter and the then Article 299 TEC (now Article 355 TFEU) limiting the application of the EC Treaty to the territory of the European Community, to find that "an act of an institution adopted pursuant to the [EC] Treaty, as a unilateral act of the Community, cannot create rights and obligations outside the territory thus defined" ${ }^{40}$ This remains the case even if that EU act adopts or incorporates the terms of an international agreement. Accordingly, Bartels reads Commune de Champagne broadly to mean that an act of the EU can never create extraterritorial legal effects because it may not assert political authority beyond the borders of the Member States. On this rationale, distant strangers will never meet the standing requirements to review an EU unilateral act on the basis of violations of their human rights extraterritorially. ${ }^{41}$ Instead they will have to repose their hopes in EU institutions or Member States who as privileged applicants are unfettered by normal standing requirements, ${ }^{42}$ but are unlikely to undertake litigation on behalf of distant strangers. ${ }^{43}$

Curiously, Commune de Champagne was not mentioned in the General Court's Polisario decision, even though it was clearly relevant. In the appeal

38 Commune de Champagne v. Council and Commission, Case T-212/02, Judgment of 3 July 2007, [2007] ECR II-2023, paras. 86-87.

39 Ibid., para. 88.

40 Ibid., paras. 89-90. See also Spira v. Commission, Joined Cases T-108/07 and T-354/08, Judgment of 11 July 2013, ECLI:EU:T:2013:367, para. 123 (Commission requests for information do not create legal rights and duties outside EU.).

41 There have been a number of cases where Kurdish nationalist movements were held to have standing to challenge EU acts placing them on lists of terrorist organizations. Kongra-Gel v. Council, Case T-253/04, Judgment of 3 April 2008, [2008] ECR II-46, and PKK v. Council, Case T-229/02, Judgment of 3 April 2008, [2008] ECR II-45. These however, are arguably not entirely 'unilateral', because they were carried out pursuant to UN Security Council Resolution 1373 (2001).

42 See Bartels, supra note 36, 1088.

43 Ibid., 1089. 
before the CJEU, the Council cited Commune de Champagne in Bartels' terms as meaning that a:

Council decision relating to the conclusion of an international agreement between the European Union and a third State has no legal effect in the territory of the other party to that agreement [...] [such that] the situation of such a territory is governed solely by the provisions adopted by that other party in the exercise of its sovereign powers. ${ }^{44}$

In the advisory opinion, however, AG Wathelet interpreted Commune de Champagne more narrowly as being relevant only to international agreements whose proper territorial scope was not contested..$^{45}$

It is submitted that AG Wathelet's reading is preferable. Strictly speaking, the General Court's comments in Commune de Champagne were both obiter and overbroad. The Court was indeed correct to find that the Swiss applicants lacked standing to bring judicial review, as whatever factual effects the EU measure adopting the international agreement may have had upon them, the legal effects were traceable solely to Switzerland as the legitimate sovereign authority over them. ${ }^{46}$ In other words, if the applicants had a problem with that international agreement, they should have taken it up with their own sovereign, not with the EU. The EU did not by its internal, unilateral act produce legal effects upon the applicants in that particular instance. However, this does not mean that the EU does not produce legal effects upon others in any other instance. In this regard, I have argued elsewhere that numerous unilateral EU measures in the areas of

44 Council v. Front Polisario, Judgment, supra note 6, para. 78. See also Council v. Front Polisario, Opinion, supra note 5, para. 55.

45 Council v. Front Polisario, Opinion, supra note 5, paras. 55-56. The CJEU avoided settling this debate by maintaining that the reference to the territory of Morocco was not to be interpreted as including the Western Sahara. Council v. Front Polisario, Judgment, supra note 6, paras. 92-99.

46 Commune de Champagne, supra note 38, para. 91. 
competition, ${ }^{47}$ data privacy, ${ }^{48}$ environmental, ${ }^{49}$ and financial ${ }^{50}$ regulation operate on a logic of "territorial extension". ${ }^{51}$ The defining characteristic of such measures is that they do not simply 'induce' desired conduct extraterritorially through influence, manipulation, or the threat of 'exclusion' from the internal market; that is, through factual effects. Instead, they include extraterritorial conduct within the scope of EU regulation by treating it as if it had taken place within the EU internal market, and thereby constitute commands producing legal effects upon distant strangers. ${ }^{52}$ The broad reading of Commune de Champagne - that the EU cannot by its internal, unilateral acts create legal effects outside the territory of the EU - is contradicted by these instances where the EU actually does create legal effects upon distant strangers. ${ }^{53}$

It may even be contradicted by prior CJEU jurisprudence. In Boukhalfa, the CJEU rejected a claim by Germany that EU freedoms could not apply to a Belgian national employed as a member of the local staff at the Belgian embassy in Algiers, under a contract subject to Algerian law. The Court rejected Germany's argument that the then Article 227 TEC - the predecessor to Article 299 TEC invoked in Commune de Champagne - limi-

47 See Ahlström Osakeyhtiö and Others v. Commission, Joined Cases 89/85, 104/85, $114 / 85,116 / 85,117 / 85$ and 125/85 to 129/85, Judgment of 27 September 1988, [1988] ECR 5193, para. 16 (Wood Pulp I).

48 See Google Spain SL v. Agencia Española de Protección de Datos (AEPD) and Mario Costeja González, Case C-131/12, Judgment of 13 May 2014, ECLI:EU:C:2014:317. See also M. Taylor, The EU's Human Rights Obligations in Relation to Its Data Protection Laws with Extraterritorial Effect, 5 International Data Privacy Law (2015), 246; N. Dobson and C. Ryngaert, Provocative Climate Protection: EU 'Extraterritorial' Regulation of Maritime Emissions, 66 International \& Comparative Law Quarterly (2017), 295.

49 See Directive (EC) 2008/101 (EU Emissions Trading Scheme Directive); Air Transport Association of America v. Secretary of State for Energy and Climate Change, Case C-366/10, Judgment of 21 December 2011, [2011] ECR I-13755.

50 See Directive (EU) 2013/36 (Capital Requirements Directive); United Kingdom v. Parliament and Council, Case C-507/13, Opinion (AG Jääskinen) of 20 November 2014, ECLI:EU:C:2014:2394, para. 37. The case went as far as the AG Conclusions stage before the UK withdrew its application.

51 A. Ganesh, The European Union's Human Rights Obligations Towards Distant Strangers, 37 Michigan Journal of International Law (2016), 475, 495-503. The concept of 'territorial extension' is borrowed, with some modification, from Scott. Cf. J. Scott, Extraterritoriality and Territorial Extension in EU Law, 62 American Journal of Comparative Law (2014), 87. See also C. Ryngaert, Jurisdiction in International Law (2015), 97-98.

52 Ganesh, supra note 51, 499-500.

53 Ibid., 530. 
ted the application of the EU Treaties to the territory of the Member States, holding instead that that "article does not... preclude Community rules from having effects outside the territory of the Community". ${ }^{44}$ Accordingly, although Commune de Champagne may be correct to the extent that an EU measure incorporating an international agreement between the EU and another legitimate sovereign does not produce legal effects upon the subjects of that other sovereign, this assumption cannot apply when neither the EU nor the other party to the treaty can claim any legitimate sovereignty over the territory and people in question. Before we address this question in Section III, we now examine how it was dealt with by the Polisario decisions and opinion.

\section{The Polisario Decisions and Opinion}

For reasons of space, this contribution does not discuss the history behind Morocco's presence in the Western Sahara following the departure of the Spanish colonial administration. Instead it takes as granted the ICJ's conclusion in its 1975 advisory opinion that there existed no tie of territorial sovereignty between the Kingdom of Morocco and the Western Sahara, such as might defeat the Sahrawi people's claim to self-determination and the formation of their own sovereign state..$^{55}$

\section{A. The General Court Decision}

One factor complicating analysis of the procedural issues was the General Court's description of the Western Sahara as "disputed territory." Such a characterization of the Western Sahara territory is difficult to reconcile with the 'individual concern' requirement, which the Front Polisario had to fulfil in order to have standing to challenge the Council decision. As Fleury Graff observes, the term 'disputed' implies that there are at least two parties concerned with the status of that territory, such that any decision creating, or modifying legal rights or obligations in the territory would by

54 Ingrid Boukhalfa v. Federal Republic of Germany, Case C-214/94, Judgment of 30 April 1996, [1996] ECR I-2253, paras. 14-15, 22.

55 Western Sahara, Advisory Opinion, supra note 1, para. 162. 
definition have to be of concern to more than just the Front Polisario. ${ }^{56}$ If so, the individual concern requirement cannot be satisfied, thus denying the Front Polisario standing. Instead, Fleury Graff suggests that "[c]e n'est, d'ailleurs, pas tant le «territoire » qui est disputé, que la " dispute » qui est " territoriale " du fait de son objet", ${ }^{57}$ and urges that the Western Sahara is more accurately described as 'occupied territory'. ${ }^{8}$ Such a conclusion would follow from the General Court's own explanation of the term 'disputed territory' as referring to "a territory in fact controlled by a non-member State, without the sovereignty of that State over that territory being recognised by the European Union and its Member States or, more generally, by all other States" ${ }^{59}$ This is self-evidently not a description of a 'disputed' territory, but of an 'occupied' one. ${ }^{60}$

56 T. Fleury Graff, Accords de Libre-Échange et Territoires Occupés: À Propos de L'arrêt TPIUE, 10 Décembre 2015, Front Polisario C. Conseil, 120 Revue Générale de Droit International Public (2016), 263, 270. See also E. Kassoti, 'The Front Polisario v. Council Case: The General Court, Völkerrechtsfreundlichkeit and the External Aspect of European Integration (First Part)', available at http://www.europeanpapers.eu/en/europeanforum/the-front-polisario-v-council-case-general-court-andvolkerrechtsfreundlichkeit (last visited 29 September 2018), (arguing that a "problematic aspect of the judgment is the examination of the substance of the action on the basis of the assumption that Western Sahara constitutes a 'disputed territory' whose 'international status is currently undetermined. In fact, the status of the territory is far from being undetermined [...]").

57 Fleury Graff, supra note 56, 270.

58 Ibid., 269-272.

59 Front Polisario v. Council, supra note 4, para. 117. See ibid., para. 232, where the General Court describes the Western Sahara in particular as "a territory [...] which is in fact administered by a non-member State, in this case the Kingdom of Morocco, although it is not included in the recognised international frontiers of that non-member State..

60 See Article 42 of the Hague Regulations of 1907 ("Territory is considered occupied when it is actually placed under the authority of the hostile army."). Regulations Annexed to Convention (IV) Respecting the Laws and Customs of War on Land, 18 October 1907, TS 539. See also Kassoti, supra note 56, ("[The] Western Sahara is an occupied territory since Morocco's presence therein meets the objective threshold of occupation under international humanitarian law, i.e. the demonstration of effective authority and control over a territory to which the occupying State holds no sovereign title.”); UN Security Council, Letter dated 29 January 2002 from Under-Secretary-General for Legal Affairs, the Legal Counsel, addressed to the President of the Security Council (12 February 2002) UN Doc. S/ 2002/161, para. 6 ("On 14 November 1975, a Declaration of Principles on Western Sahara was concluded in Madrid between Spain, Morocco and Mauritania (the Madrid Agreement), whereby the powers and responsibilities of Spain, as the administering Power of the territory, were transferred to a temporary tripartite ad- 
Before this could be addressed, however, the General Court had to deal with the question of whether the Front Polisario constituted a 'natural or legal person' for the purposes of Article 263(4) TFEU. The Front Polisario insisted that it was "not a legally constituted body according to the law of any State, whether internationally recognised or not", and that as "the incarnation of the sovereignty of the Sahrawi people", it could not be required "to produce evidence of its constitution according to the national law of an internationally recognised State". ${ }^{11}$ In the end, the General Court accorded it personality, but under EU law, under a jurisprudence emphasizing twin criteria of independence from the will of others, and responsibility; that is, being able to have one's actions attributed to oneself. ${ }^{62}$ In particular, the General Court likened the Front Polisario to the applicant in Groupement des Agences de voyages, where an ad hoc association of travel agencies that formed in order to respond to a tender was held to possess personality on grounds that "the Commission could not challenge the capacity to institute proceedings of a body that it had allowed to participate in an invitation to tender and to which it had addressed a negative decision after a comparative examination of all the tenderers" ${ }^{63}$ Finally, the General Court cited $P K K$ and $K N K v$. Council - an action for annulment where two organizations challenged certain restrictive measures placed upon them for

ministration. The Madrid Agreement did not transfer sovereignty over the territory, nor did it confer upon any of the signatories the status of an administering Power - a status which Spain alone could not have unilaterally transferred.").

61 Front Polisario v. Council, supra note 4, paras. 40-41. The Italian Court of Cassation has held that national liberation movements enjoy a form of 'objective legal personality' under international law independent of recognition by other sovereign states, which is a political consideration. Arafat and Salah, Italian Court of Cassation, Judgment no. 1981 of 28 June 1985, paras 884-889.

62 See Front Polisario v. Council, supra note 4, para. 49, finding that find that entities have personality when "their constitutional structures were such as to endow them with the necessary independence to act as responsible bodies in legal matters [...]" Citing Union syndicale-Amalgamated European Public Service Union and others v. Council, Case 175/73, Judgment of 8 October 1974, [1974] ECR 917, paras. 9-17; Syndicat Général du Personnel des Organismes européens v. Commission, Case 18/74, Judgment of 8 October 1974, [1974] ECR 933, paras. 5-13. See also Front Polisario v. Council, supra note 4, para. 51, citing Lassalle v. Parliament, Case 15/63, Order of 14 November 1963, [1963] ECR 50, 51 (personality implies the possession of a measure of "independence and responsibility, even if limited.").

63 Groupement des Agences de voyages v. Commission, Case 135/81, Judgment of 28 October 1982, [1982] ECR 3800, paras. 9-12. Cited at Front Polisario v. Council, supra note 4 , para. 48 . 
the purpose of combating terrorism - for the contention that where an entity is regarded:

$[\ldots]$ as having an existence sufficient to be the subject of [...] restrictive measures [...] consistency and justice required that that entity be recognised as having the capacity to challenge that decision. ${ }^{64}$

The mislabelling of the Western Sahara as 'disputed territory', and its recognition of the Front Polisario as a person only under EU law, lead to an extremely peculiar analysis of the issues regarding standing. Recall that the decision being challenged was a legislative act not explicitly addressed to the Front Polisario, and that the Plaumann doctrine therefore applied in full. ${ }^{65}$ In order to satisfy the 'individual concern' requirement, it had to be the case that no other person could lay claim to similar rights relating to the Western Sahara. The Court reasoned that the aforementioned "effects on the legal position of the whole territory" were of direct concern to the Front Polisario on account of the fact that:

[t] he definitive international status of that territory [had] not yet been determined and [had to] be determined in UN-led negotiations between the Kingdom of Morocco and, specifically, the Front Polisario. ${ }^{66}$

However, this only means that the Front Polisario had an interest in the conclusive determination of the legal rights pertaining to that territory, and 'interests' are not the same as rights.

Even if this objection is ignored, the fact that the Front Polisario may play an integral role in the UN-led negotiations is not enough to satisfy the individual concern requirement. Recall that the applicant in Plaumann was denied standing because in principle any other person could have entered the clementine business, but that the applicant in Codorniu was recognized to have standing because, having taken out a trademark in Spain, it alone had the right to call its product 'crémant.' Therefore, for the Front Polisario to have standing, it had to be the case that no one else could rightfully have taken part in those negotiations. None of this would obtain if the Front Polisario was endowed with personality only under EU law in the manner of an ordinary private person. Instead, for the Front Polisario to have standing, one would have to take seriously its claim to be the incarnation of the

64 PKK and KNK, Case C-229/05 P, Judgment of 18 January 2007, ECLI:EU:C:2007:32, paras. 109-112. Cited at Front Polisario v. Council, supra note 4, para. 50.

65 Front Polisario v. Council, supra note 4, paras. 71-73.

66 Ibid., para. 110. 
Sahrawi people, and a person at international law. ${ }^{67}$ The Council made precisely this argument before the CJEU, which AG Wathelet in principle agreed with in his second theory. ${ }^{68}$ As we shall see, however, he would have denied the Front Polisario standing nonetheless. ${ }^{69}$

After thus disposing of these procedural questions, the General Court heard eleven different substantive pleas from the Front Polisario, all but one of which it rejected. Of particular interest for our purposes are the two instances where the General Court broached possible claims by individual Sahrawis. In the first, it considered whether the EU Charter of Fundamental Rights, read together with Article 6 TEU and Article 67 TFEU, could be invoked to invalidate the Association Agreement on grounds of human rights violations by Moroccan authorities. ${ }^{70}$ It concluded that they could not, with the terse declaration that "no absolute prohibition derives, either from those provisions or from those of the Charter of Fundamental Rights, which precludes the EU from concluding an agreement with a third State on trade in agricultural products, processed agricultural products, fish and fishery products which may also be applied to a territory controlled by that third State even though its sovereignty over that territory has not been internationally recognised" ${ }^{71}$ Second, it considered whether the EU was prohibited from entering into the Association Agreement by Articles 3(5) and $21 \mathrm{TEU}$, and Article $205 \mathrm{TFEU}$, which commit the EU to protecting and advancing human rights in all its relations with the wider world. ${ }^{72}$ Again, it concluded that they did not, on the marginally less opaque reasoning that because:

[t]he EU institutions enjoy a wide discretion in the field of external economic relations which covers the agreement referred to by the contested decision... it cannot be accepted that it follows from the 'values on which the European Union is based, or the provisions relied on by the Front Polisario..., that the conclusion by the Council of an agree-

67 Fleury Graff, supra note 56, 283. ("Pour autant, il ne fait guère de doute que le Front Polisario jouit d'une personnalité juridique internationale.”), citing Reparations for Injury Suffered in the Service of the United Nations, Advisory Opinion, ICJ Reports 1949, 174, 179.

68 Council v. Front Polisario, Opinion, supra note 5, paras. 184-185.

69 Ibid., paras. 201, 212 (denying that the requirements of direct and individual concern are satisfied.).

70 Front Polisario v. Council, supra note 4, paras. 143-148.

71 Ibid., para. 146.

72 Ibid., paras. 159-167. 
ment with a third State which may be applied in a disputed territory is, in all cases, prohibited. ${ }^{73}$

These pronouncements echo the Court's major theme of there being no 'absolute' prohibition at international law against concluding agreements that will be applied on 'disputed' (read 'occupied') territory. ${ }^{74}$

The sole reason the Court gave for the annulment was an apparent administrative omission: ${ }^{75}$

Given the fact, inter alia, that the sovereignty of the Kingdom of Morocco over Western Sahara is not recognised by the European Union or its Member States, or more generally by the UN, and the absence of any international mandate capable of justifying Moroccan presence on that territory, the Council, in the examination of all the relevant facts of the present case, with a view to exercising its wide discretion as to whether or not to conclude an agreement with the Kingdom of Morocco which may also apply to Western Sahara, should have satisfied itself that there was no evidence of an exploitation of the natural resources of the territory of Western Sahara under Moroccan control likely to be to the detriment of its inhabitants and to infringe their fundamental rights. ${ }^{76}$

Incredibly, the scope of the assessment required by the General Court appears to cover the entire catalogue of rights in the EU Charter of Fundamental Rights. ${ }^{77}$ Because the Council had failed to carry out such an assessment, the General Court held that the Council decision fell to be annulled to the extent the Association Agreement applied in the Western Sahara. ${ }^{78}$

\section{B. Before the CJEU}

The first of the three theories AG Wathelet presented - which eventually became the basis for the CJEU's decision - was pitted squarely against the General Court's premise that international agreements purporting to bind third parties are not 'absolutely' prohibited, and therefore implicitly per-

73 Ibid.

74 Ibid., para. 215.

75 Ibid., paras. 225-247.

76 Ibid., para. 241.

77 Ibid., para. 228.

78 Ibid., para. 247. 
mitted. Pointing to the Western Sahara's status as a non-self-governing territory under Article $73 \mathrm{UNC}$, as well as settled practice by EU Member States and other states recognizing the Western Sahara as such, ${ }^{79}$ AG Wathelet rejected the General Court's 'disputed territory' terminology, concluding that the Western Sahara "cannot be part of the territory of the Kingdom of Morocco within the meaning of [... the EU-Morocco] Association" ${ }^{80}$ The Association Agreement was not to be interpreted as covering the Western Sahara. From this point onwards, two sleights of hand take place.

In the second of his arguments, AG-Wathelet invoked the Article 34 VCLT rule on the relative effect of treaties (pacta tertiis nec nocent nec prosunt), which broadly prohibits parties to a treaty creating rights or obligations for a third party without its assent. ${ }^{81}$ Within EU jurisprudence, that principle featured most famously in Brita, a preliminary reference which concerned whether goods produced in Israeli settlements in the West Bank were entitled to preferential treatment according to the terms of an association agreement between the EU and Israel. The CJEU held that they were not: the provisions of the EC-Israel Association Agreement could not be interpreted in a manner infringing upon rights that had been accorded to Palestinian authorities under a separate EC-PLO Protocol. The reasoning was twofold. On the one hand, the EC-Israel agreement did not positively require Member State authorities to accord preferable treatment to goods produced in West Bank settlements. On the other hand, the EC-PLO agreement obligated the same Member State authorities to provide preferential treatment to goods produced in the territory of the West Bank only on the basis of certificates issued by PLO authorities. ${ }^{82}$

In its Polisario decision, the General Court had held that the rule of the relative effect of treaties was inapplicable because there was no parallel agreement between the EU and the Front Polisario from which the latter could derive rights that might be raised in opposition to the provisions of the EU-Morocco Association Agreement. ${ }^{83}$ This holding was reversed on

79 Council v. Front Polisario, Opinion, supra note 5, paras. 73-81.

80 Ibid., para. 82.

81 Ibid., paras. 101-112. Vienna Convention on the Law of Treaties, 23 May 1969, 1155 UNTS 331 (VCLT), Article 34 provides that "A treaty does not create either obligations or rights for a third State without its consent." Article 38 contains an exception for erga omnes obligations and customary rules of international law.

82 Firma Brita GmbH v. Hauptzollamt Hamburg-Hafen, Case C-386/08, Judgment of 25 February 2010, [2010] ECR I-1289, paras. 44-45, 52, 56-58.

83 Front Polisario v. Council, supra note 4, paras. 95-97. 
appeal. As the Western Sahara was a non-self-governing territory rather than a 'disputed' one, the Advocate General and the CJEU reasoned that it was a third party to the EU-Morocco Association Agreement. ${ }^{84}$ Thus, the EU-Morocco agreement could not bind it without its consent. Such consent had not been given, so the treaty could not be interpreted as purporting to apply in the territory of the Western Sahara. Finally, since it did not apply to the Western Sahara, the Front Polisario had no legal interest in challenging the EU measure adopting it, and therefore lacked standing. ${ }^{85}$

Next comes the discussion of what is called 'de facto application' of the agreement to the Western Sahara. By that term, AG Wathelet and the CJEU referred to (1) the inclusion of, and extension of tariff preferences to, 140 companies based in the Western Sahara in the list of approved foreign exporters contained in the schedules to the Association Agreement; and (2) the multiple visits by officials from the Commission's Food and Veterinary Office to the Western Sahara to ensure compliance by Moroccan authorities with EU health standards.$^{86}$ At no point did the Council or the Commission deny that these visits actually happened. Before the General Court, the Commission "confirm(ed) the presence on the list of approved exporters... of undertakings established in Western Sahara" but argued that they were merely there "as a matter of convenience". 87 Before the CJEU, the Council conceded that it knew that the preferential terms accorded by the Association Agreement were to be extended to exports coming from the Western Sahara, but argued that this did not amount to "recognition, acquiescence or acceptance" of Morocco's claim to sovereignty over that territory. ${ }^{88}$

In the opinion, AG Wathelet dismissed this attempt by the Council effectively to plead its own bad faith, describing it as a strategy of "applica-

84 Council v. Front Polisario, Judgment, supra note 6, para. 106; Council v. Front Polisario, Opinion, supra note 5 , paras. 105,108 . The precise identity of 'it' is unclear. For the CJEU, the third party is the 'people' of the Western Sahara, while AG Wathelet's third party defines it as the 'territory', but then proceeds to refer interchangeably to that, the people, and their representatives.

85 Council v. Front Polisario, Opinion, supra note 5, paras. 105-112; Council v. Front Polisario, Judgment, supra note 6, paras. 100-108.

86 See Front Polisario v. Council, supra note 4, paras. 79-80; Council v. Front Polisario, Opinion, supra note 5, paras. 98-99. The CJEU is much more guarded, speaking only of "the facts set out in paragraphs 77 to 87 of [the General Court] judgment." Council v. Front Polisario, Judgment, supra note 6, para. 117.

87 Front Polisario v. Council, supra note 4, para. 80.

88 Council v. Front Polisario, Opinion, supra note 5, para. 67. 
tion without recognition" 89 Nevertheless, he ultimately concluded that the presence of 140 Western Sahara-based companies on the list of approved exporters was irrelevant, because "those exporters are also established in Morocco,... and for that reason are entitled to benefit from the [Association Agreement] ${ }^{\prime 90}$ while the visits by Commission officials did not constitute implementation of the Association Agreement in the Western Sahara "since they are not provided for" in the same. ${ }^{91}$ Instead, framing the discussion as concerning subsequent practice possibly effecting a variation of a treaty, ${ }^{92} \mathrm{AG}$ Wathelet argued that the instances of 'de facto application' did not qualify as such because the parties were not of one mind: Morocco viewed the Western Sahara as an integral part of its territory while the EU did not. ${ }^{93}$ Accordingly, because the EU-Morocco Association Agreement was not applicable to the Western Sahara, the Front Polisario once again had no "legal interest" in the Council decision adopting it, nor was it of direct and individual concern to it. ${ }^{94}$

In the judgment, the CJEU adopted both the argument on the relative effect and on 'de facto application.' The first line of its findings observes that "the conclusion of the General Court... that the Liberalisation Agreement 'also applies to the territory of Western Sahara' is based, not on a finding of fact, but on a legal interpretation of that agreement made by the General Court on the basis of Article 31 of the Vienna Convention".95 Following from this, the CJEU points out that:

[i]n order to be able to draw correct legal conclusions from the absence of a stipulation excluding Western Sahara from the territorial scope of the Association Agreement, in interpreting that agreement, the General Court was bound not only to observe the rules of good faith interpretation... pursuant to which the interpretation of a treaty

89 Ibid., paras. 67, 80.

90 Ibid., para. 99.

91 Ibid., para. 98.

92 Ibid., para. 91. Citing Europäische Schule München v. Oberto and O'Leary, Joined Cases C-464/13 and C-465/13, Judgment of 11 March 2015, ECLI:EU:C:2015:163.

93 Ibid., paras. 87-100.

94 Ibid., para. 114.

95 Council v. Front Polisario, Judgment, supra note 6, para. 81, referring to Front Polisario v. Council, supra note 4 , paras. $73,88,98-102$. 
must be carried out by taking account of any relevant rules of international law applicable in the relations between the parties [...]. ${ }^{96}$

These rules included the principle of self-determination, Article 29 VCLT on the territorial scope of treaties, and the relative effect of treaties. ${ }^{97}$ The first two of these meant that the words 'territory of the Kingdom of Morocco' contained in Article 94 of the Association Agreement were not to be interpreted as meaning the territory of Western Sahara," 98 while the relative effect of treaties meant that the agreement could not apply to the Western Sahara in the absence of consultation of the Sahrawis. ${ }^{99}$

Second, because instances of 'de facto' implementation of the Agreement "would necessarily be incompatible with the principle that Treaty obligations must be performed in good faith, which nevertheless constitutes a binding principle of general international law applicable to subjects of that law who are contracting parties to a treaty", ${ }^{100}$ it followed that recognizing them as subsequent practice:

[...] would necessarily have entailed conceding that the European Union intended to implement those agreements in a manner incompatible with the principles of self-determination and of the relative effect of treaties, even though the European Union repeatedly reiterated the need to comply with those principles [...]. ${ }^{101}$

This would "necessarily be incompatible with the principle that Treaty obligations must be performed in good faith, which nevertheless constitutes a binding principle of general international law [... ${ }^{102}$ Accordingly, the General Court erred:

[...] in holding that the subsequent practice referred to in [its] judgment $[\ldots]$ justified an interpretation of those agreements as meaning that they were legally applicable to the territory of Western Sahara. ${ }^{103}$

96 Ibid., para. 86, citing Brita, supra note 82, para. 43, and, Kadi and Al Barakaat International Foundation v. Council and Commission, C-402/05 P and C-415/05 P, Judgment of 3 September 2008, [2008] ECR I-06351, para. 291.

97 Council v. Front Polisario, Judgment, supra note 6, para. 87.

98 Ibid., para. 108.

99 Ibid., paras. 106-107.

100 Ibid., para. 124.

101 Ibid., para. 123.

102 Ibid., para. 124.

103 Ibid., para. 125 . 
As such, the CJEU's Polisario decision does not simply narrow or block access to judicial review by throwing up the direct and individual concern requirements. Instead, it closes it off completely, by denying that the Council decision produced any legal effect upon the Front Polisario. The rule of relative effect of treaties, which is meant to prevent two international persons from joining forces to exploit another, becomes a means by which to deny that third person the right to complain of the exploitation. As for the instances of 'de facto application', while AG Wathelet merely mischaracterises them, the CJEU decision denies their reality outright. In both of these instances, the sleight of hand consists in sublimating the fact that the EUMorocco Association Agreement was actually applied to the Western Sahara, with the question of whether it should have been applied there. The fact that there is a legal prohibition against others punching you does not mean they are factually incapable of doing so, or that the black eye they give you is merely 'de facto' and therefore irrelevant. The whole reason why the legal prohibition exists is because people are capable of punching each other, and actually do so from time to time. Likewise, the fact that EU institutions may be legally prohibited from entering into an agreement with another state that it knows will be wrongfully applied upon the territory of yet another, does not mean that it is factually incapable of doing so, as the Council conceded in its 'application without recognition' argument. 'De facto application' is just a euphemism for illegal application.

\section{Legal Effects, Authority, and Individual Sahrawis}

This section argues that the Council decision adopting the Association Agreement creates legal effects not just upon the Front Polisario, but also upon the individual Sahrawis whom the Front Polisario represents. Unlike the applicants in Commune de Champagne, individual applicants caught up in a Polisario-like situation may properly claim that the Association Agreement and the decision adopting it produce legal effects upon them. Such transactions between the EU and Morocco constitute assertions of authority over individual Sahrawis by the EU, which in principle should give them standing; that is, the right to hold the EU to account. 


\section{A. Legal Effects and the Fiduciary Nature of Authority}

Recall the discussion in Section II(A) concerning the themes of independence and responsibility running through the EU jurisprudence on legal personality. Such ideas about personhood are neither unique nor original, but hearken to the idea of a free person being sui iuris, or subject to his or her own law. ${ }^{104}$ In contrast, a 'thing' is "an object of free choice", to which "nothing can be imputed" ${ }^{105}$ In this sense, a persons' fundamental status their 'dignity' - lies in not being treated as a thing; that is, not being dominated or instrumentalized as a thing at the mercy of another. ${ }^{106}$ On such a conception of human dignity, persons normally may not unilaterally change the legal rights and obligations of others; that is, exercise authority over them. If that were generally possible, all persons would become potentially subject to the choices of everyone else; they would be dominated and instrumentalized as things at the mercy of all others. The relative effect of treaties can be explained in such terms: two international persons cannot by agreement between themselves alter the legal rights and obligations of a third person. To hold otherwise would be to treat that third international person as a thing at the disposal of the treaty parties, which is contrary to their dignity as a free equal in the international legal order. ${ }^{107}$

If dignity is understood as freedom from domination, there are only two kinds of persons who may change another's legal rights and obligations unilaterally. As suggested earlier in section I(A), these are fiduciaries, and authorities. ${ }^{108} \mathrm{~A}$ growing body of literature argues that the concept of

104 See I. Kant, The Metaphysics of Morals, in M. J. Gregor (ed.), Practical Philosophy (2006), 353, 378 [Ak $\$ 6: 223$ ] (defining a person as "a subject whose actions can be imputed to him" he is "subject to no other laws than those he gives to himself.").

105 Ibid., 378 [Ak \$6:223].

106 Ibid., 393 [Ak $\$ 6: 237$ ] ("Freedom (independence from being constrained by another's choice), insofar as it can coexist with the freedom of every other in accordance with a universal law, is the only original right belonging to every man by virtue of his humanity.").

107 See Island of Palmas (The Netherlands v. United States), Award of Max Huber, 2 RIAA 1928, 829, 842 ("[...] whatever may be the right construction of a treaty, it cannot be interpreted as disposing of the rights of independent third Powers"); M. Huber, Annuaire de l'Institut de Droit International (1931), vol. 36-I, 79 ("[...] le droit international, comme tout droit, repose sur l'idée de la coexistence de volontés de la même valeur.").

108 See P. Miller, Justifying Fiduciary Duties, 58 McGill Law Journal (2013), 969, 1012-1013 ("fiduciary power is not properly understood as connoting relative strength, ability, or influence [...] [but] ought to be understood as a form of au- 
an authority in public law is itself fundamentally an extension of the concept of a fiduciary in private law. ${ }^{109}$ The awesome discretionary powers accorded to fiduciaries and political authorities are compatible with the selflawgiving nature of persons only on the condition that they exercise these powers for their beneficiaries'/subject's purposes, never their own. ${ }^{110}$ For this reason, the rights and obligations of authorities vis-à-vis their subjects in public law are structurally identical to those imposed upon fiduciaries towards their beneficiaries in private law. ${ }^{111}$ Thus expressed, the fiduciary model of authority applies not just to traditional Westphalian sovereigns, but to:

[...] any entity exercising non-consensual administrative powers over individuals-whether it be an international body such as the UN Inter-

thority... [meaning the ability to] render rightful conduct that would otherwise be wrongful."); Frame v. Smith, [1987] 2 S.C.R. 99, para. 60 (Supreme Court of Canada) (Wilson J., dissenting, defining a fiduciary relation as one where: “(1) the fiduciary has scope for the exercise of some discretion or power; (2) the fiduciary can unilaterally exercise that power or discretion so as to affect the beneficiary's legal or practical interests; and (3) the beneficiary is peculiarly vulnerable to or at the mercy of the fiduciary holding the discretion or power.").

109 See P. Finn, 'The Forgotten 'Trust': The People and the State', in M. Cope (ed.), Equity: Issues and Trends (1995), 131 ("Beyond the trust, beyond the company, the most fundamental of fiduciary relationships in our society is that which exists between the community (the people) and the State and its agencies...”) Justice Finn continues, observing that "much more so than in the private sector, it was-and is - in the realms of government that fiduciary power is the most pervasive, the most intense, and its abuse, the most threatening to the community and to its trust in its institutions., ibid., 132. For theorists proceeding from a notion of dignity as freedom from domination, see P. Pettit, Republicanism: A Theory of Freedom and Government (1997), 8 ("The commonwealth or republican position [...] sees the people as trustor, both individually and collectively, and sees the state as trustee: in particular, it sees the people as trusting the state to ensure a dispensation of non-arbitrary rule."); E. Fox-Decent, Sovereignty's Promise: The State as Fiduciary (2011), 93-105; A. Ripstein, Force and Freedom: Kant's Legal and Political Philosophy (2009), chapter 7. For an argument proceeding from a welfare-based notion of dignity, see E. Benvenisti, Sovereigns as Trustees of Humanity: On the Accountability of States to Foreign Stakeholders, 107 The American Journal of International Law (2013), 295.

110 Kant defines the third category of private right as consisting in "a right to a person akin to a right to a thing (ius realiter personale)," which he explicates as "possession (though not use) of another person as a thing." Kant, supra note 104, 412 (Ak 6:260).

111 Ibid., 451, (Ak 6:306) (public law contains "no further or other duties than can be conceived at private law.'). 
im Administration for East Timor, a subnational government such as the State of New York, or a political/paramilitary group such as Hezbollah [...]. ${ }^{112}$

Similarly, albeit on a different conception of the nature of fiduciary obligation, Benvenisti argues that the:

[...] argument for applying the trusteeship concept for the global context begins with the same insight - that every sovereign State or any other body it created or it permitted to act is an agent. ${ }^{113}$

It is trite that the EU creates law directly binding upon persons. ${ }^{114}$ Accordingly, the fiduciary model of authority must apply equally to the EU as it does to Westphalian sovereigns.

By conceptualizing (1) human dignity in terms of independence, (2) the unilateral creation of legal effects as implying fiduciary relations, and (3) political authority in terms of fiduciary accountability, we can simultaneously explain why Commune de Champagne was correct to hold that the EU did not produce any legal effects upon the Swiss applicants in that case, as well as why the opposite should apply for both the Front Polisario, and an individual Sahrawi applicant.

\section{B. The Relative Effect of Treaties Revisited}

In situations like Commune de Champagne, a treaty between international parties is analogous to a contract between two private trustees. Ordinarily, legitimate political authorities are presumed to be entitled to modify the

112 E. J. Criddle and E. Fox-Decent, Fiduciaries of Humanity: How International Law Constitutes Authority (2016), 116. See generally ibid., chapter 8 on "International Institutions as Trustees of Humanity".

113 E. Benvenisti, The Law of Global Governance (2014), 134. See also ibid., 98-99, 130-131 (describing the obligations of accountability of the UN Mission in Kosovo (UNMIK) in fiduciary terms).

114 N.V. Algemene Trans.-en Expeditie Onderneming van Gend en Loos v. Nederlandse administratie der belastingen, Case 26/62, Judgment of 5 February 1963, [1963] E.C.R. 1. The decision is suggestive of entrustment and fiduciary obligation, for instance when it recognizes "the Community [as constituting] a new legal order of international law for the benefit of which the States have limited their sovereign rights, albeit within limited fields, and the subjects of which comprise not only Member States but also their nationals", and that this not only "imposes obligations on individuals but is also intended to confer upon them rights which become part of their legal heritage., ibid., 2, 12. 
legal positions of their subjects, and the counterparty has no reason to question this. Therefore, all changes in any individual subject's legal position are traceable to their own sovereign. This changes if one party has affirmative knowledge that the counterparty will be in violation of their obligations to their subjects. The situation may be analogized to dishonest or knowing assistance in procuring a breach of trust in English law, under which a trustee's:

[...] legal power and control over the trust property [...] may no doubt be extended in equity to others who are not properly trustees, if they are found either making themselves trustees de son tort, or actually participating in any fraudulent conduct of the trustee to the injury of the cestui que trust. ${ }^{115}$

Similarly, the law on international responsibility of states and international organizations recognizes secondary liability for aiding or assisting international wrongs when states and international organizations have (1) knowledge of the circumstances of the internationally wrongful act, and (2) that act would be wrongful if committed by the state or international organization itself. ${ }^{116}$ While there is a lively debate in private law as to whether the standard for knowing assistance in a breach of trust is dishonesty or negligence, ${ }^{117}$ the consensus at international law is that:

[t] he aid or assistance must be given with a view to facilitating the commission of the wrongful act, and must actually do so. ${ }^{118}$

115 Barnes v. Addy, (1874) LR 9 Ch App 244, 251-252 (English Court of Appeal).

116 Articles on Responsibility of States for Internationally Wrongful Acts, in Report of the International Law Commission on the Work of Its Fifty-Third Session, Articles 16, at 47, UN GAOR, 56th Sess., Supp. No. 10, at 43, UN Doc. A/56/10 (2001); Articles on the Responsibility of International Organizations, annexed to UNGA Res 66/100, Article 14, UN Doc. A/Res./66/100, 27 Feb. 2012.

117 See Royal Brunei Airlines v. Tan [1995] UKPC 4 (UK Privy Council) (holding the correct standard as dishonesty rather than negligence or unconscionability); Farah Constructions Pty Ltd v. Say-Dee Pty Ltd, [2007] HCA 22 (High Court of Australia) (requiring a more fine-grained assessment of the third-party's and the trustee's dishonesty). See also, Dubai Aluminium Company Ltd v. Salaam [2002] UKHL 48 (UK House of Lords). Cf. Air Canada v. M \& L Travel Ltd. [1993] 3 SCR 787 (Supreme Court of Canada) ("It is unnecessary [...] to find that the appellant himself acted in bad faith or dishonestly.").

118 J. Crawford, The International Law Commission's Articles on State Responsibility: Introduction, Text and Commentaries (2002), 149, para. 5. See also H. P. Aust, Complicity and the Law of State Responsibility (2011), 235 ("It thus appears that the ILC wants Article 16 [ARSIWA] to be interpreted narrowly so that 
This is an incredibly high standard which can be satisfied only in the most unusual of cases. Accordingly, Bartels observes that:

[i]t is doubtful that a party negotiating a trade agreement will ever know with the requisite degree of certainty that a given obligation will result in a violation of human rights obligations. ${ }^{119}$

He does, however, suggest one exception: an agreement to export instruments of torture. ${ }^{120}$

At this point it must be emphasised that the procedural rules under EU law for purposes of admissibility before the EU courts cannot simply be modelled upon the substantive rules at international law as to what constitutes assisting an international wrong. The question for our purposes is 'procedural': does the EU owe a claimant an obligation of accountability because it has established itself as an authority over them? This is not the substantive question of whether it has breached those obligations. That comes later - at the merits. The question is not whether international wrongs committed by Morocco in the exploitation of the Western Sahara are attributable to the EU as a matter of international law, ${ }^{121}$ but whether the EU, by entering into the Association Agreement with Morocco, formed the sort of relationship with individual Sahrawis in which it could legitimately be expected to hear their grievances and do them the courtesy of a reply in the courts of the EU. Thus expressed, the legal analysis is as follows: in a Commune de Champagne-type scenario, the procedural obligation of accountability is contingent upon affirmative knowledge of a substantive wrong by the treaty counterparty: the EU is accountable to a distant stranger only if it was affirmatively aware that that person's sovereign would rely upon the treaty to violate her rights. In a Polisario-type scenario, however, this symbiotic relationship between procedural and substantive rules is disrupted. This is because when the treaty arrangement is to be ap-

the 'knowledge' element turns into something more akin to a requirement of wrongful intent."); Case Concerning the Application of the Convention on the Prevention and Punishment of the Crime of Genocide, Judgment, para. 421 ("There is no doubt that the conduct of an organ or a person furnishing aid or assistance to a perpetrator of the crime of genocide cannot be treated as complicity in genocide unless at the least that organ or person acted knowingly, that is to say, in particular, was aware of the specific intent (dolus specialis) of the principal perpetrator.") (emphasis added).

119 Bartels, supra note 36, 1081.

120 Ibid.

121 The Council attempted to argue this before the General Court. See, Front Polisario v. Council, supra note 4, para. 230. 
plied upon the territory of a third state, the presumption that the counterparty speaks for the people of that territory does not hold.

This is apparent in the basic principles of the law of occupation. Article 42 of the Hague Regulations 1907 provides that:

Territory is considered occupied when it is actually placed under the authority of the hostile army. ${ }^{122}$

And Article 43 of the same imposes upon such an occupant an obligation to maintain order and public life in the territory. ${ }^{123}$ In other words, the occupant is in a fiduciary relationship with the ousted sovereign:

[o]ccupation does not transfer sovereignty. Instead, it transfers to the occupant the authority to exercise some of the rights of sovereignty. The occupant, therefore, exercises a temporary right of administration, on a trusteeship basis until the occupation ceases in one way or another. ${ }^{124}$

This, however, is not the end of the occupant's fiduciary obligations. As Benvenisti explains, the current Fourth set of Geneva Conventions develop upon the Hague Regulations to envisage a much more expansive role for the occupant with regards to governing the territory, whereby it is "a proactive regulator, [and] no longer the disinterested watch guard envisioned in the Hague Regulations". ${ }^{25}$ In this spirit, Benvenisti argues that "the emerging principles of self-determination, of human and minority rights" mean

122 This provision has been preserved in subsequent treaties and has become customary international law. See E. Benvenisti, The International Law of Occupation (2012), 44 [Benvenisti, Ocupation], citing Prosecutor v. Naletilić \& Martinović, Case No. IT-98-34-T, Judgment of 31 March 2003, para. 217.

123 The authentic text of Article 43 of the Hague Regulations of 1907 provides that "L'autorité du pouvoir légal ayant passé de fait entre les mains de l'occupant, celui-ci prendra toutes les mesures qui dépendent de lui en vue de rétablir et d'assurer, autant qu'il est possible, l'ordre et la vie publics [...]" The first English version mistranslated the phrase 'la vie publics' as 'safety'. See Benvenisti, Ocupation, supra note 122,68 , fn. 1 .

124 G. von Glahn and J. L. Taulbee, Law Among Nations: An Introduction to Public International Law (2015), 635. See also A. Roberts, What Is a Military Occupation?, 55 British Yearbook of International Law (1985), 249, 294-295.

125 Benvenisti, Ocupation, supra note 122, 74. Geneva Convention Relative to the Protection of Civilian Persons in Time of War (Fourth Geneva Convention), 12 August 1949, 75 UNTS 287. 
that "the occupant's status is conceived to be that of a trustee" not just of the ousted sovereign, but also of the population under occupation. ${ }^{126}$ Unlike a sovereign which can be presumed to have the same interests as its subjects, an occupying power:

$[\mathrm{m}] \mathrm{ust}$ attend to at least three sets of interests: its own security interests, the interests of the ousted government, and those of the local population, which may be different from the interest of their legitimate government. ${ }^{127}$

All occupations are united by one characteristic regardless of whether they are rightful, wrongful, 'belligerent', 'pacific', 'wartime', or 'military': there is "a potential - if not inherent - conflict of interest between the occupant and occupied". ${ }^{28}$ The implications of this conflict of interest with respect to the exploitation of natural resources are reflected in treaty provisions, such as Hague Regulations Article 47 prohibiting pillage, and in case law imposing a duty of vigilance upon the occupant. ${ }^{129}$ The inherent conflict of interest between the occupant and the population of the occupied territories means that any party entering into an agreement with the occupant in respect of the occupied territory is immediately put on notice of the potential for exploitation, and that the onus is upon them to ensure that this does not happen. For this reason, the General Court was entirely correct to dismiss the Council's argument that it was "solely for the Kingdom of Morocco to ensure that the exploitation of the natural resources is beneficial to the inhabitants of the part of Western Sahara it controls",130 and to hold that the duty of due diligence has special salience in the particular case of occupied territories like the Western Sahara. ${ }^{131}$ Because the EU institutions had ignored the obvious - indeed inherent - conflict of interest between Morocco on the one hand, and the Front Polisario and the people of the Western Sahara on the other, they risked entangling the EU in breaches

126 Benvenisti, Ocupation, supra note 122, 6-7. See ibid., $72-76$ (detailing the evolution of the occupant's duties from being mainly about preserving the rights of the ousted sovereign to becoming focused upon the welfare of the occupied people and protecting their human rights.); Criddle and Fox-Decent, supra note 112, 192-196 (describing the general recognition that occupants have human rights obligations towards the occupied people.).

127 Benvenisti, Ocupation, supra note 122, 69.

128 Ibid., 3-4.

129 Ibid., 81-82; Armed Activities on the Territory of the Congo (Democratic Republic of the Congo v. Uganda), Judgment, ICJ Reports 2005, 165, paras. 247-248.

130 Ibid., para. 240.

131 Ibid., para. 232. 
committed by Morocco with regard to both, thereby making it potentially accountable to the Front Polisario and the Sahrawi people as a 'constructive' fiduciary. Accordingly, the General Court was correct to hold that the EU Institutions had committed not just an ordinary error, but a 'manifest' error of assessment, requiring the decision to adopt the Agreement to be quashed.

\section{Conclusion: A gap in the complete system of remedies}

When it adopted the EU-Morocco Association, the EU placed itself in a fiduciary relationship with the Front Polisario and with individual Sahrawis; that is, a relationship of authority. Thus, in principle, both the Front Polisario and individual Sahrawis ought to have had standing to challenge the Council decision adopting the Association Agreement. As such, the requirements of direct and individual concern would have posed unjustifiable barriers with respect to both of them. In this regard, consider that in his second rationale, AG Wathelet acknowledged the Front Polisario as the legitimate representative of the Sahrawi people in the "political process", and accordingly recognized that the Council decision produced legal effects upon it. ${ }^{132}$ Nevertheless he opined that it did not fulfil the criteria of direct and individual concern, because the Council decision might also have been of interest to the Kingdom of Spain as the entity officially tasked with administering the Western Sahara under Article 73 of the UN Charter. ${ }^{133}$ Thus, the undisputed legitimate representative of the Sahrawi people would nonetheless be denied standing on account of a speculative interest on the part of a colonial power that had abandoned any claims or obligations relating to the Western Sahara three decades ago. In the wake of the CJEU's decision, however, the application would not be allowed to get even that far, but would instead be dismissed outright for lack of legal effects.

The Polisario decision unmasks a thoroughgoing rottenness in the notion of the EU's Volkerrechtsfreundlichkeit, ${ }^{134}$ as well as certain deeper prob-

132 Council v. Front Polisario, Opinion, supra note 5, paras. 175, 185-186.

133 Ibid., paras. 186-91, 201, 212.

134 E. Cannizzaro, The Neo-Monism of the European Legal Order, in E. Cannizzaro et al. (eds.), International Law as Law of the European Union (2011), 35, 57 (arguing that the jurisprudence of the CJEU as particularly open to the reception of international law norms). Cf. J. Klabbers, The European Union in International Law (2012), 77. For a useful survey of the literature, see J. Odermatt, The Court 
lems in the nature of the EU as a constitutional order. Regarding the former, the EU's self-presentation as conscientious global citizen with a particularly ardent devotion to international law makes its officials believe that it can do no wrong. ${ }^{135}$ For the General Court, it is somehow not illegal for the EU to enter into a treaty disposing of the rights of a non-party: there is no 'absolute' prohibition against it, as long as steps are taken to ensure that the exploitation of natural resources conduces to, or does not detract too much from, the benefit of the inhabitants of that territory. ${ }^{136}$ The CJEU's decision is more insidious: if the EU Can Do No Wrong, and exploiting a third party by treaty is Wrong, then it simply did not happen. The listing of 140 companies in the Western Sahara in the schedules to the Association Agreement, the preferential tariff treatment given to them for decades, the multiple visits by the Commission officials to the territory at the invitation of Moroccan authorities; these are völkerrechtsunfreundlich, and therefore "too illegal to be true". 137 They must therefore be disregarded as "factual anomalies falling outside the scope of appeal".138

As for the implications of Polisario upon the EU's claim to be a constitutional order, the case serves as yet another example of the CJEU's steadfast opposition to affording individuals the right to challenge EU measures through judicial review. As demonstrated in section $\mathrm{I}(\mathrm{B})$, the jurisprudence often treats such standing and other 'procedural' matters as merely of secondary importance, which can be safely restricted since there are other

of Justice of the European Union: International or Domestic Court International Organisations and Courts, 3 Cambridge Journal of International and Comparative Law (2014), 696, 697-700.

135 See R. Kagan, Of Paradise and Power: America and Europe in the New World Order (2003), 3 (describing the EU as particularly committed to consensus and multilateralism, while the US remained "mired in history, exercising power in the anarchic Hobbesian world where international laws and rules are unreliable [...]"); J. D. Ohlin, The Assault on International Law (2015), 8 (describing an attitude among 'conservative' U.S. lawyers towards "international legal norms that flow from faraway European cities like Brussels, Geneva, and The Hague.”).

136 Front Polisario v. Council, supra note 4, paras. 234-247.

137 V. Kube, 'The Polisario Case: Do EU Fundamental Rights Matter for EU Trade Policies?', available at http://www.ejiltalk.org/the-polisario-case-do-eu-fundamental-rights-matter-for-eu-trade-polices/ (last visited 29 September 2018).

138 S. Hummelbrunner and A.-C. Prickartz, 'EU-Morocco Trade Relations Do Not Legally Affect Western Sahara - Case C-104/16 P Council v. Front Polisario', 5 January 2017, available at https://europeanlawblog.eu/2017/01/05/eu-moroccotrade-relations-do-not-legally-affect-western-sahara-case-c-10416-p-council-vfront-polisario/ (last visited 29 September 2018). 
substitutes such as the preliminary ruling procedure. ${ }^{139}$ However, that would not be acceptable even if they were available to distant strangers like the Sahrawi applicants, because, as mentioned earlier, the purpose of preliminary rulings is to ensure uniform interpretation and application of EU law. They are emphatically not designed as avenues for claimants to vindicate their rights. A claimant in a preliminary reference is not the master of her claim: that honour belongs to the national judge making the reference. ${ }^{140}$ Having dignity means not just being treated 'rightly' by others, but having standing, or the 'right' to demand rightful treatment from others as a matter of obligation. Ultimately, standing goes to the heart of what it means to be a subject empowered with rights, rather than an object of pity. It is therefore a cause for concern if standing is improperly denied or restricted, and this remains the case even if the eventual outcome of the dismissal is otherwise welcome.

139 See also Jégo-Quéré, supra note 2, para. 35 (overruling an expansive interpretation of the then applicable rules on standing on grounds that the measure concerned could have been challenged before national courts indirectly).

140 Rhimes, supra note 10, 159-160 (describing the discretion of national court judges in crafting the precise question to be referred, which may differ from what the litigants themselves desire). 